\title{
CYSTIC DUPLICATION OF STOMACH: A CASE REPORT
}

\author{
Ivona Djordjević1,2, Andjelka Slavković1,2, Zoran Marjanović1, \\ Dragoljub Živanović1, ${ }^{1}$, Ana Kostić ${ }^{\text {, Danijela Djerić }}{ }^{1}$
}

\begin{abstract}
Cystic gastric duplications represent an extremely rare surgical entity. Persistent vomiting is the most common clinical presentation due to its compressive effect on pylorus. Additional confusion is created by their localization mimicking pyloric stenosis.

A female infant at 3 months of age was admitted to the clinic for persistent postprandial vomiting and weight loss. Abdominal $X$ ray examination confirmed the presence of aeroliquid levels in the upper abdominal portions. Echosonographic and NMR examination indicated the presence of bilocular cystic formation in the region of the pylorus, near visceral contour of the spleen, with a total diameter of $31 \mathrm{~mm}$.

Two partially interconnected cystic formations forming hourglass mass were found during surgery. The complete enucleation was done. Postoperatively, a rapid recovery occurred and the child was discharged home on the $5^{\text {th }}$ day. Pathohistological finding: the lesion corresponds to cystic duplication, with pylorus type mucosa.

Peripyloric cysts are an extremely rare clinical entity. Symptomatology is conditioned primarily by a mechanical, compressive effect on the pylorus, which, differentially diagnostically, often mimics pyloric stenosis. Therapy is surgical.
\end{abstract} Acta Medica Medianae 2020;59(1):139-143.

Key words: cystic duplication, stomach, children

${ }^{1}$ Pediatric Surgery Clinic, Clinical center, Niš, Serbia

2University of Niš, Faculty of Medicine, Niš, Serbia

Contact: Đorđević Ivona

48 Dr. Zorana Djindjića Blvd., 18000 Niš, Serbia

E-mail: ivonadj74@gmail.com

\section{Introduction}

Cystic duplications are defined as spherical lesions surrounded by a muscular wall that is in intimate contact with the associated part of the digestive tube. They can be located along the entire length of the digestive tract from the mouth to the anus. They represent the result of a defect in the gut. These are extremely rare developmental disorders (1/4000-5000). They are most commonly localized in the small intestine (40\%), and extremely rare $(<5 \%)$ in gastric projection (1). The most common localization of cystic duplications is an area of great curvature, and at the level of the pylorus are exclusive. Clinical manifestations depend on location, size, and mucosal pattern. Rarely seen in adults because of their compressive effect, vomiting, and symptoms of gastric outlet obstruction, or even palpable mass, they are diagnosed at an early age, in $2 / 3$ of cases appear before one year of age (2). Very often, they contain ectopic pancreatic tissue, lymphatic tissue and respiratory epithelium.

\section{Case report}

A female infant at 3 months of age was admitted to the Clinic for persistent vomiting after each meal and weight loos. Physical examination, routine blood tests and biochemistry were unremarkable. Abdominal $X$ ray examination confirms the presence of aeroliquid levels in the upper abdominal portions. Echosonographic (Figure 1) and NMR examination indicate the presence of bilocular cystic formation in the region of the pylorus, near visceral contour of the spleen, with a total diameter of $31 \mathrm{~mm}$.

The patient underwent an exploratory laparotomy. Two partially interconnected cystic formations forming hourglass mass were found during surgery. The smaller lesion was of solid and thick walls in intimate contact with the pylorus. The narrow canal was connected to a larger cyst ( $30 \mathrm{~mm}$ ) lying in the meso between the colon and the stomach, thin walls filled with liquid content (Figure 2). The complete enucleation was done (Figure 3 ). The cyst was separated by a sharp and blunt preparation from most of the pylorus canal. The part of the pylorus duct in 
intimate contact with the cyst was open longitudinally and the part of the wall was resected together with the cyst and then closed transversely, preserving the patency of the pyloric lumen (Figure 4).

Histopathologic examination of the lesion re- vealed a $3 \mathrm{~cm}$ bilocular cyst, with pylorus type mucosa and well-developed ectopic pancreatic tissue.

In the postoperative period, a rapid recovery occurred and the child was discharged home on the $5^{\text {th }}$ day after the intervention.

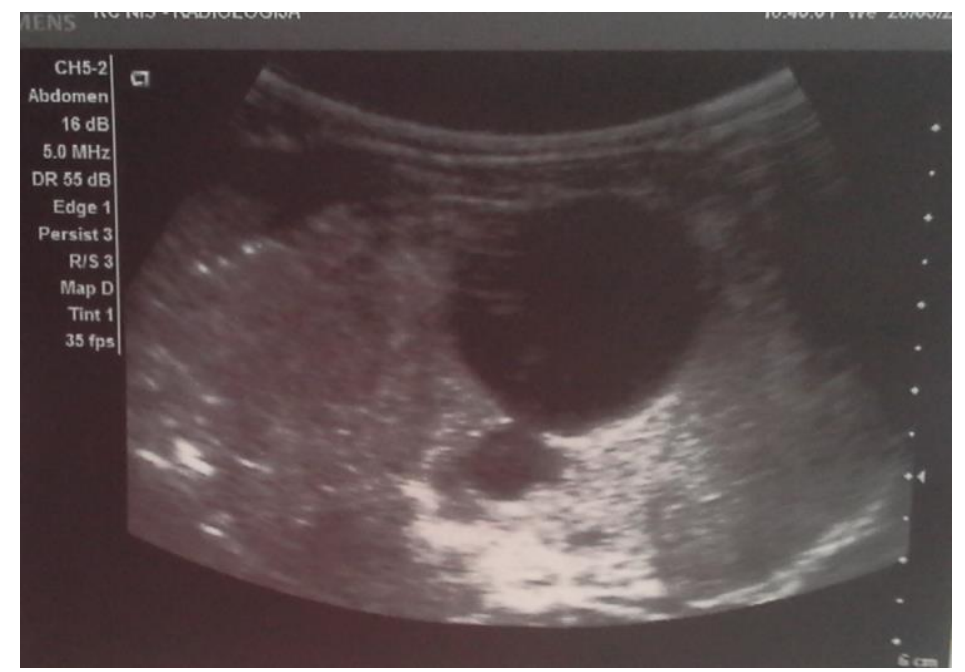

Figure 1. Echosonographic examination revealed the presence of bilocular cystic formation, in the region of the pylorus

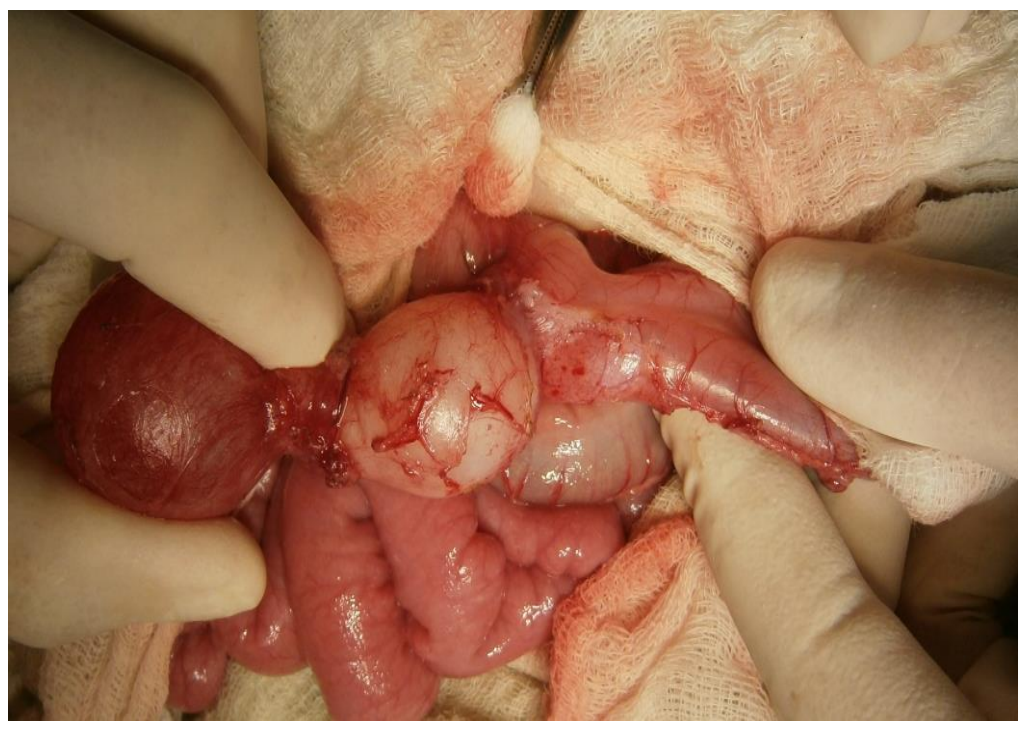

Figure 2. Two partially interconnected cystic formations forming hourglass mass. Cysts are connected with a narrow canal 


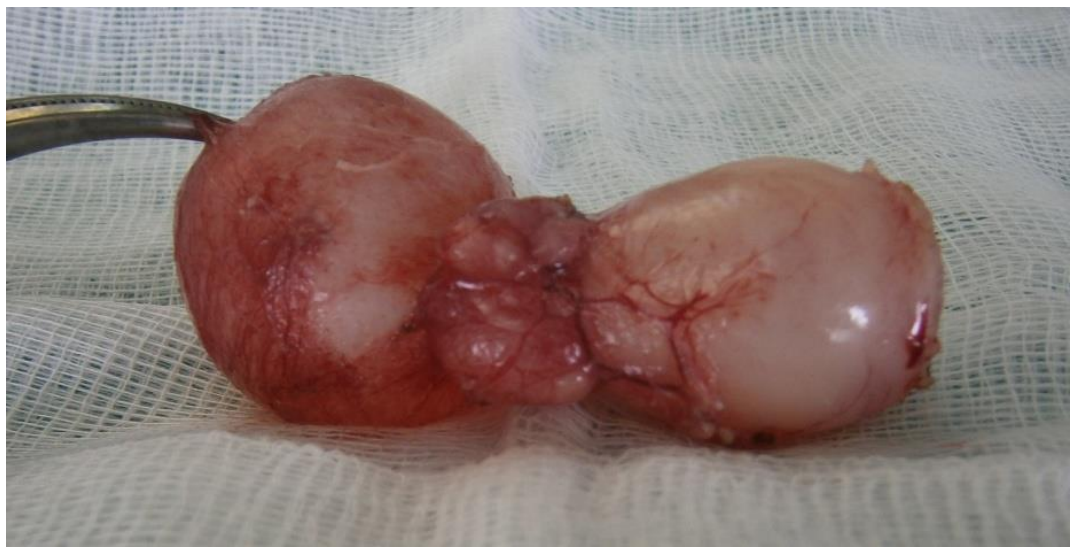

Figure 3. Complete enucleated hourglass cyst

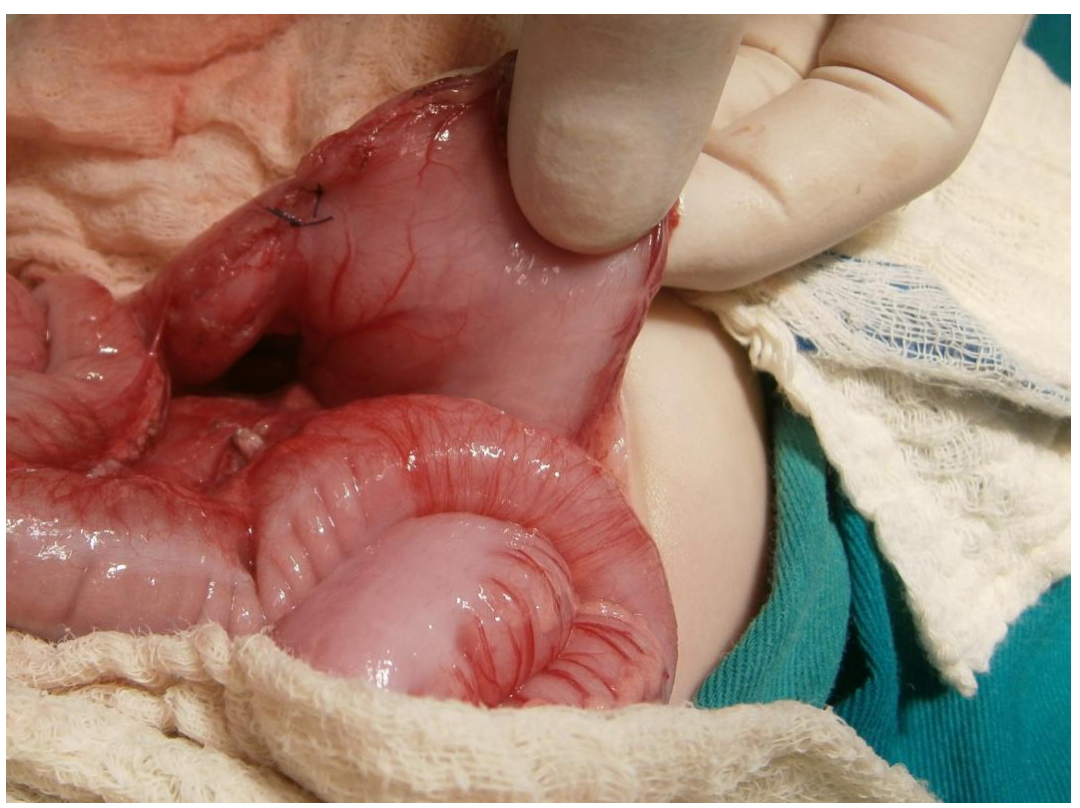

Figure 4. Appearance of pylorus after enucleation of the cyst

\section{Discussion}

Duplications of gastrointestinal tract are very rare congenital anomalies. They occur along the entire digestive tube and are most rarely in the projection of the pylorus $(<5 \%)$, with the majority of patients diagnosed within the first 3 months of life and rarely in adults (2).

The basic criteria for the diagnosis of cystic duplication of the stomach are: a. common wall between the cyst and adjacent portion of the stomach; b. the cyst is in spherical shape surrounded by a muscular tissue, that extends to the muscular layer of the wall of the stomach; c the cyst is covered by the stomach type mucosa or mucosa of other parts of the digestive tube $(3,4)$.

There is no definite explanation in the literature regarding the occurrence of cystic gastric duplications. Several theories have been proposed but none has been proven. Bremer proposed the theory of errors of recanalization and fusion of longitudinal folds (5), while McLetchie suggested that adhesion of notochord and embryonic endoderm might not elongate as quickly as its surrounding structures, causing traction diverticulum leading to duplication cyst formation (5). Hypoxia, persistent embryonic diverticulum are just some of the theories.

The clinical presentation can be very different from asymptomatic cases to patients with abdominal pain to nausea, vomiting, weight loss, dysphagia, and epigastric mass on physical examination (3). As in our case of pyloric localization of the cyst nonbilious vomiting and weight loss may be the dominant symptom. A very small subset of patients can remain asymptomatic. 
The most common location of cyst is the distal greater curvature, communicating or noncommunicating with the gastric lumen (6). Presence of gastric and ectopic pancreatic tissues, what is most common entity is associated with complications such as bleeding, perforation, peptic ulcer, pancreatitis or even malignancy (7).

Ultrasound is a noninvasive imaging modality used as first tool in infants for examining the upper gastrointestinal tract. In the majority of the cases it shows hypoechogenic cystic lesion in the upper abdomen seen usually adjacent to the stomach, pancreas, the liver and biliary tracts.

Imaging studies including the CT and MRI are important to determine the cystic nature of the lesion as well as its extent and relation with the adjacent structures.
The purpose of treatment is complete surgical excision of the cyst (8). It is recommended not only for symptomatic relief as seen with a gastric outlet obstruction, but also because of the risk of malignant degeneration. There are published 14 cases of adenocarcinoma diagnosed in gastric cystic duplications (9). If malignancy is suspected, surgical resection is the golden standard.

\section{Conculsion}

Peripyloric cysts are an extremely rare clinical entity. Symptomatology is conditioned primarily by a mechanical, compressive effect on the pylorus, which, differentially diagnostically, often mimics pyloric stenosis. Therapy is surgical in all patients, and especially if malignancy is suspected.
1. Doepker MP, Ahmad SA. Gastric duplication cyst: a rare entity. J Surg Case Rep 2016; 5:rjw073. [CrossRef] [PubMed]

2. Takazawa S, Uchida H, Kawashima H, Tanaka Y, Sato $\mathrm{K}$, Jimbo $\mathrm{T}$, et al. Laparoscopic partial gastrectomy of a huge gastric cyst duplication in an infant. Nagoya J Med Sci 2015;77:219-96. [PubMed]

3. Johnston J, Wheatley GH, El Sayed HF, Marsh WB, Ellison EC, Bloomston M. Gastric duplication cysts expressing carcinoembryonic antigen mimicking cystic pancreatic neoplasms in two adults. American Surgeon 2008;74(1):91-4. [PubMed]

4. Horne G, Ming-Lum C, Kirkpatrick AW, Parker RL. High-grade neuroendocrine carcinoma arising in a gastric duplication cyst: a case report with literature review. International Journal of Surgical Pathology 2007;15(2):187-91. [CrossRef] [PubMed]
5. Kim DH, Kim JS, Nam ES, Shin HS. Foregut duplication of the cyst of the stomach. Pathology International 2000;50(2):142-5. [CrossRef] [PubMed]

6. Menon $\mathrm{P}$, Rao KL, Saxena AK. Duplication cyst of the stomach presenting as hemoptysis. Eur J Pediatr Surg 2004;14:429-31. [CrossRef] [PubMed]

7. Stephen TC, Bendon RW, Nagaraj HS, Sachdeva R. Antral duplication cyst: a cause of hypergastrinemia, recurrent peptic ulceration, and hemorrhage. J Pediatr Gastroenterol Nutr 1998;26:216-8.

[CrossRef] [PubMed]

8. Perek A, Perek S, Kapan M, Goksoy E. Gastric duplication cyst. Dig Surg 2000;17:634-6. [CrossRef] [PubMed]

9. Zhu Y, LV L, Pan W, Ren P, Han T. Gastric duplication complicated by malignant transformation in adults: report of three cases. J Gastrointest Dig Syst 2015; 5:2-8. [CrossRef] [PubMed] 


\title{
CISTIČNA DUPLIKACIJA ŽELUCA - PRIKAZ SLUČAJA
}

\author{
Ivona Đorđevići, ${ }^{2}$, Anđelka Slavković1,2, Zoran Marjanović ${ }^{1}$, \\ Dragoljub Živanović1, ${ }^{1,}$, Ana Kostić ${ }^{1}$, Danijela Đerić ${ }^{1}$
}

${ }^{1}$ Klinika za pedijatrijsku hirurgiju, Klinički centar Niš, Niš, Srbija

2Univerzitet u Nišu, Medicinski fakultet, Niš, Srbija

Kontakt: Ivona Đorđević

Bulevar dr Zoran Đinđić 48, 18000 Niš, Srbija

E-mail: ivonadj74@gmail.com

Cistične duplikacije želuca predstavljaju izuzetno redak hirurški entitet. Zbog kompresivnog delovanja na pilorus, uporno povraćanje predstavlja najčešću kliničku prezentaciju. Dodatnu konfuziju stvara njihova lokalizacija, te često diferencijalno-dijagnostički upućuju na stenozu pilorusa.

Žensko novorođenče u 3. mesecu života primljeno je u kliniku zbog upornog povraćanja, posle svakog obroka, i nenapredovanja. Nativna grafija trbuha potvrđuje prisustvo hidrogasnih nivoa u gornjim partijama trbuha. Ehosonografski i NMR pregledi ukazuju na prisustvo bilokularne cistične formacije, u regiji pilorusa i uz viscelarnu konturu slezine, ukupnog promera $31 \mathrm{~mm}$.

Intraoperativno je evidentirana promena izgleda peščanog sata, koju čine dve delom međusobno povezane cistične formacije. Učinjena je kompletna enukleacija cisti. Postoperativno, dolazi do brzog oporavka i dete je 5. dana otpušteno kući. Patohistološki nalaz: lezija odgovara cističnoj duplikaciji sa mukozom pilorusnog tipa.

Peripilorične ciste predstavljaju izuzetno redak klinički entitet. Simptomatologija je uslovljena, pre svega, mehaničkim, kompresivnim efektom na pilorus, što diferencijalno-dijagnostički često imitira stenozu pilorusa. Terapija je hirurška.

Acta Medica Medianae 2020;59(1):139-143.

Ključne reči: cistična duplikacija, želudac, deca 